\title{
Pengembangan pembelajaran kewarganegaraan perspektif kosmopolitanisme
}

\author{
Lili Halimah ${ }^{a, 1^{*}}$ \\ a Program Studi PPKn Jurusan PIPS STKIP Pasundan, Cimahi, Jawa Barat \\ ${ }^{1}$ lilihalimah@gmail.com \\ * korespondensi penulis
}

\begin{abstract}
ABSTRAK
Tulisan ini mengajukan masalah utama seberapa besar dampak kosmopolitanisme dalam terhadap pembelajaran pendidikan kewarganegaraan. Riset ini menggunakan perspektif studi kosmopolitanisme yang didukung perspektif teori situasional dan teori relasional. Lokasi penelitian tersebar di Kota Cimahi Jawa Barat. Populasi penelitian berjumlah 20.702 orang dan sampel penelitian berjumlah 400 peserta didik. Pendekatan yang digunakan adalah pendekatan kuantitatif dengan metode survey cross-sectional. Data diambil melalui kuesioner dan uji kompetensi, dianalisis dengan menggunakan analisis Structural Equation Modeling. Hasil penelitian menunjukkan bahwa dampak kosmopolitanisme terhadap pendidikan kewarganegaraan memiliki angka yang cukup signifikan (dengan $\mathrm{R} 2=0,6971$ atau 69,71\%). Karena itu, perlu adanya proses harmonisasi kosmopolitanisme bagi siswa-siswi sekolah menengah dalam pembelajaran pendidikan kewarganegaraan. Kosmopolitanisme memiliki efek lebih tinggi terhadap pendidikan kewarganegaraan $(31,44 \%)$. Kosmopolitanisme yang dipelajari dalam pembelajaran pendidikan kewarganegaraan memiliki efek pada siswa-siswi sekolah menengah di Cimahi, sebesar 13,42\%. Kosmopolitanisme menjadi faktor krusial dalam mengembangkan kualitas pembelajaran pendidikan kewarganegaraan di tengah proses globalisasi. Hal ini memberikan implikasi bahwa pemerintah perlu meninjau kembali kurikulum pendidikan kewarganegaraan, agar siswa tidak terpengaruh budaya global yang negatif dan pola pikir yang dapat mencabut nilai-nilai keindonesiaan.
\end{abstract}

Kata kunci: globalisasi, kosmopolitanisme, pembelajaran, pendidikan kewarganegaraan

\section{ABSTRACT}

This study is the result of research on building Civics through the perpective cosmopolitanism. In the era of globalization, the Indonesian people are faced with the major powers in tandem with globalization cosmopolitanism. Based on this, the main problem is formulated that is how strong research in the learning process cosmopolitanism Civics. This work utilizes a variety of perspectives in the study of cosmopolitanism, which is supported by the perspective of the theory of situational, and relational theory. Location of the study are spread throughout Central Cimahi, North, and South. The study population amounted to 20702 and a sample of 400 participants. The aprroach used is quantitative and methods Cross-Sectional Survey. The collection of data collected by distributing questionnaires and conduct tests competency tests are processed by the analysis of Structural Equation Modeling. The results of the study is that the impact of cosmopolitanism against Civics already significant learning (with $R 2=0.6971$ or $69.71 \%$ ). This suggests a process of harmonization of cosmopolitanism in middle school students in learning civics. Cosmopolitanism has the effect of higher (31.44\%) of the civics lesson. It shows that cosmopolitanism that learned in civics learning process has an effect on middle school students in Cimahi for although only $13.42 \%$. Cosmopolitanism be a crucial factor in developing quality learning Civics, quality and meaning amid the strengthening of globalization. This has implications for the government to review the studies curriculum Civics with regard realities that exist in society with regard to globalization flowing so feared behavior of learners in Cimahi dragged into negative global culture and the impact on the mindset of seta life style that can uproot the culture and people of Indonesian.

Keywords: globalization, cosmopolitanism, civic learning, civic education

Copyright $@ 2018$ Universitas Ahmad Dahlan, All Right Reserved

\section{PENDAHULUAN}

Bangsa Indonesia pada era globalisasi ini dihadapkan pada kekuatan utama yakni kosmopolitanisme yang beriringan dengan globalisasi. Held et.al (1999) dan Giddens (2004) mengajukan gagasan atas "globalisasi" yang memiliki kecenderungan "negatif", seperti mendorong consumerisme, homogenisasi tertentu yang membawa efek negatif pada identitas lokal, hal tersebut disebabkan globalisasi akan dapat mengancam budaya bangsa sehingga budaya kosmopolitan yang dihasilkan 
oleh globalisasi akan muncul dan dapat mematikan budaya nasional atas suatu bangsa (Tilaar, 2002, hal. 4). Dalam pengertian lain, kosmopolitanisme merujuk kepada suatu paham atau gagasan bahwa semua manusia, tanpa memandang latar belakangnya adalah anggota dari sebuah komunitas (Kalidjernih, 20094). Kosmopolitanisme mengarahkan kepada suatu kehidupan yang "tanpabatas" (borderless) yang erat kaitannya dengan globalisasi sehingga dianggap sebagai ideologi yang menganggap semua kelompok etnis manusia milik sebuah komunitas tunggal berdasarkan pada moralitas bersama.

Kota Cimahi merupakan sebuah kota yang potensial untuk membuka diri dengan segala hal dan pernah akan dicanangkan sebagai Cimahi Cyber City artinya Kota yang siap menjadi pusat pelatihan dan ruang interaksi bagi pengembangan industri kreatif di lingkup Jawa Barat. Hal ini merupakan tantangan yang harus dihadapi oleh kota-kota yang mengalami pertumbuhan cepat dalam menyusun kebijakan dan program pendidikan yang mampu menghasilkan manusia-manusia cakap dan memiliki karakter yang didukung oleh penguatan dalam pewarisan budaya dan identitas bangsanya. Hasil observasi menunjukkan peserta didik banyak berinteraksi dengan media sepulang sekolah ataupun di hari libur. Hal ini berdampak pada perilaku dan gaya hidup peserta didik, karena menganggap media sebagai guru kedua mereka.

Dari pengamatan penulis ke beberapa sekolah di kota Cimahi, gaya mengajar guru pendidikan kewarganegaraan (PKn) cenderung monoton tanpa menggunakan media sebagai sarana pembelajaran, sehingga guru tersebut tidak membantu mengatasi kebosanan peserta didik ketika mengajar di dalam ataupun di luar kelas, sehingga tingkat pemahaman peserta didik berada pada tahap yang kurang menggembirakan. Bahkan ada guru PKn yang bukan berlatar belakang PKn. Ini berpengaruh terhadap kualitas peserta didik yang diharapkan. Mata pelajaran PKn yang dikemas secara menarik akan membuat peserta didik menyenanginya, merasa perlu, tidak menjadi beban, dan merasakan manfaat setelah mempelajarinya. Selain akan mengubah citra bahwa mata pelajaran PKn membosankan. Guru harus mampu menampilkan pribadi yang menyenangkan di hadapan peserta didik.

Tulisan ini mengkaji proses membangun pembelajaran PKn melalui perpektif kosmopolitanisme untuk menjawab dua permasalahan utama, yaitu seberapa kuat kosmopolitanisme berpengaruh terhadap pembelajaran PKn? dan sejauhmana pengaruh nilai kosmopolitan secara langsung dan melalui pembelajaran PKn? Atas pertanyaan itu, penulis mengajukan hipotesis mayor bahwa nilai kosmopolitan memiliki kontribusi dalam pembelajaran PKn, dan hipotesis minor bahwa nilai kosmopolitan berpengaruh secara langsung terhadap pembelajaran PKn. Dua hal ini muncul didasarkan atas pemikiran bahwa pembelajaran PKn merupakan program yang secara programatik prosedural berupaya memanusiakan (humanizing) dan membudayakan (civilizing) serta memberdayakan peserta didik (diri dan kehidupannya) supaya menjadi warga negara yang baik sebagaimana tuntutan keharusan/yuridis konstitusional bangsa/ negara yang bersangkutan.

PKn dalam paradigma baru mengusung tujuan utama yakni mengembangkan kemampuan dasar "civic competencies" yakni civic knowledge (pengetahuan dan wawasan kewarganegaraan), civic disposition (nilai, komitmen, dan sikap kewarganegaraan), dan civic skills (perangkat keterampilan intelektual, sosial, dan personal kewarganegaraan) yang seyogyanya dikuasai oleh setiap individu warga negara (Winataputra, 2004, hal. 317-318).

Sekaitan dengan konsep kosmopolitanisme, dapat digambarkan bahwa sebagai orientasi, kosmopolitanisme berkaitan dengan 'kemauan untuk terlibat dengan lainnya. Hal tersebut memerlukan keterbukaan intelektual dan estetika terhadap pengalaman budaya yang berbeda, mencari kontras daripada keseragaman' (Mau, Mewes, \& Zimmermann, 2008, hal. 3).

Delanty (2006) menyebut, bahwa konsep kosmopolitanisme dapat dikenali melalui dua arus, yakni sebagai konsepsi kuat kewarganegaraan dan demokrasi. Pendekatan ini melihat kosmopolitan sebagai manifestasi fundamental dalam konteks politis yang dihadirkan dari globalisasi. Dalam pendekatan normatif ini, terdapat komitmen kuat terhadap universalisme. Kosmopolitanisme dipahami sebagai satu moral ideal yang mencakup dimensi pandangan tentang praktik dari individu dan kelompok yang mana walau secara analisa berbeda, pada hakikatnya terkait pada taraf dari hakikat empiris.

Kalidjernih (2009, hal. 4) menyatakan bahwa "kosmopolitanisme merujuk kepada suatu paham atau gagasan bahwa semua manusia, tanpa memandang latar belakangnya adalah anggota dari sebuah komunitas". Selanjutnya dalam kaitannya dengan globalisasi, ternyata globalisasi berdampak secara nyata bagi kehidupan masyarakat dunia, seperti yang dikemukan oleh Micklethwait dan Wooldridge (2008) dengan istilah the five myths of globalization, salah satunya yakni: globalisasi telah memunculkan berbagai produk global; globalisasi telah mengakhiri bisnis yang bersifat tradisional; dan globalisasi telah menjadikan batas-batas secara geografi tidak menjadi masalah lagi. 
Proses kosmpolitanisme adalah fenomena global dan merupakan ancaman pada identitas kebangsaan. Fenomena itu telah melemahkan bentuk-bentuk identitas kebudayaan suatu bangsa bahkan identifikasi global mulai mendislokasikan dan menggantikan identifikasi nasional (Kalidjernih, 2011, hal. 55-56). Interdepedensi global menimbulkan pecahnya identitas kebangsaan dan kultural lainnya dan arus golabalisasi tersebut menciptakan munculnya "identias bersama (shared identities), yang disebut kosmopolitanisme, atau dalam konsep lain disebut homogenisasi kultural.

Mengapa homogenisasi kultural terjadi? Kalidjernih (2011, hal. 57) menguraikan: semakin kehidupan sosial dimediasi oleh pemasaran global dari gaya, tempat, dan citra, oleh perjalanan internasional dan jaringan citra media dan sistem komunikasi global, identitas semakin terpisahtercerabut dari waktu ke waktu, tempat-tempat, sejarah-sejarah, dan tradisi yang spesifik, dan muncul 'terapung bebas'. Menurut pendapat Oommen (2009, hal. 56), nasionalisme juga memberikan bentuk dari etnisitas, namun memiliki sifat yang lebih khusus. Kelompok etnis tidak selalu bertindak bersama kecuali ketika mereka memiliki kepentingan khusus untuk saling melindungi.

\section{METODE}

Penelitian ini merupakan penelitian crosssectional survey pada sekolah menengah di Kota Cimahi. Jumlah populasi sekolah menengah di Kota Cimahi sebesar 20.702 sebagaimana tergambar pada tabel 1 berikut:

Tabel 1 Populasi peserta didik sekolah menengah Kota Cimahi

\begin{tabular}{clcc}
\hline No & Sekolah & $\begin{array}{c}\text { Jumlah } \\
\text { Sekolah }\end{array}$ & $\begin{array}{c}\text { Jumlah Peserta } \\
\text { didik }\end{array}$ \\
\hline 1. & SMA negeri & 6 & 5.172 \\
\hline 2. & SMA swasta & 10 & 2.403 \\
\hline 3. & MA swasta & 7 & 438 \\
\hline 4. & MA negeri & 1 & 428 \\
\hline 5. & SMK negeri & 3 & 2.770 \\
\hline 6. & SMK swasta & 19 & 9.491 \\
\hline & Jumlah & 46 & 20.702 \\
\hline
\end{tabular}

Sumber: Dinas Pendidikan Kota Cimahi (2012)
Jumlah sampel peserta didik adalah 421 orang peserta didik, sebagaimana tergambar pada tabel 2 berikut:

Tabel 2 Sampel peserta didik sekolah menengah Kota Cimahi

\begin{tabular}{clccc}
\hline No & Sekolah & $\begin{array}{c}\text { Popu- } \\
\text { lasi }\end{array}$ & $\begin{array}{c}\text { Sam- } \\
\text { pel }\end{array}$ & $\begin{array}{c}\text { Jumlah } \\
\text { Peserta didik }\end{array}$ \\
\hline 1. & SMA negeri & 6 & 2 & 94 \\
\hline 2. & SMA swasta & 10 & 2 & 80 \\
\hline 3. & MA negeri & 1 & 1 & 41 \\
\hline 4. & MA swasta & 7 & 2 & 80 \\
\hline 5. & SMK negeri & 3 & 1 & 46 \\
\hline 6. & SMK swasta & 19 & 2 & 80 \\
\hline & Jumlah & 46 & 10 & 421 \\
\hline
\end{tabular}

Sumber: Dinas Pendidikan Provinsi Jawa Barat (2012)

Pendekatan yang digunakan dalam penelitian ini adalah pendekatan kuantitatif. Peneliti melakukan pencatatan dan penganalisaan data hasil penelitian menggunakan perhitungan statistik dengan metode cross-sectional survey. Metode ini digunakan karena peneliti hanya mengobservasi fenomena pada peserta didik di Kota Cimahi pada satu titik waktu tertentu secara bersamaan sehingga mampu menjelaskan hubungan nilai kosmopolitan, dan pembelajaran PKn pada populasi yang diteliti.

Strategi analisis data yang digunakan meliputi analisis deduktif, analisis induktif, dan bersamaan dengan langkah kedua, melalui data angket hasil uji coba dan teknik analisis yang sama dilakukan pengujian validitas eksternal atau kriteria (criteria validity). Instrumen yang dikembangkan adalah angket, pedoman observasi, pedoman wawancara, dan teknik pengumpulan data melalui penyebaran kuesioner, pengamatan secara langsung, wawancara mendalam, dan studi dokumentasi.

Analisis data meliputi pengolahan data dan penggunaan statistik parametrik. Dari sisi pengolahan data, kriteria untuk mengukur tinggirendahnya hubungan dan pengaruh variabel dependen terhadap variabel independen sebagai berikut:

Tabel 3 Kriteria pengukuran hubungan dan pengaruh

\begin{tabular}{|c|c|c|c|c|c|c|c|c|}
\hline \multicolumn{3}{|c|}{ Korelasi (R) } & \multicolumn{2}{|l|}{ Kategori } & \multicolumn{3}{|c|}{$\begin{array}{l}\text { Pengaruh } \\
\text { (R-Square) }\end{array}$} & Kategori \\
\hline 0,000 & - & 0,199 & Sangat Lemah & $\rightarrow$ & 0,000 & - & 0,039 & Sangat Rendah \\
\hline 0,200 & - & 0,399 & Lemah & $\rightarrow$ & 0,040 & - & 0,159 & Rendah \\
\hline 0,400 & - & 0,599 & Cukup Kuat & $\rightarrow$ & 0,160 & - & 0,359 & Cukup Tinggi \\
\hline 0,600 & - & 0,799 & Kuat & $\rightarrow$ & 0,360 & - & 0,639 & Tinggi \\
\hline 0,800 & - & 1,000 & Sangat Kuat & $\rightarrow$ & 0,640 & - & 1,000 & Sangat Tinggi \\
\hline
\end{tabular}

Sumber: Toharuddin (2012: 136) 
Analisis data dilakukan dengan menggunakan statistik parametrik berupa data interval atau rasio. Untuk beberapa variabel menggunakan data ordinal, sehingga diperlukan pengubahan skala ordinal menjadi skala interval dengan menggunakan Method of Succesive Interval (MSI). Syarat berikutnya, data harus memenuhi persyaratan normalitas dan homogenitas karena jumlah sampel lebih dari 400 responden dengan penarikan sampel secara acak sederhana dan berasal dari populasi yang homogen.

Untuk mengetahui gambaran mengenai masing-masing variabel dilakukan dengan analisis deskriptif dengan menggambarkan data yang telah terkumpul untuk membuat generalisasi hasil penelitian termasuk teknik analisis data statistik deskriptif yakni melalui tabel, grafik, diagram, persentase, frekuensi, dan perhitungan mean. Sedangkan untuk menguji hipotesis hubungan antarvariabel penelitian dilakukan melalui uji korelasi zero order atau bivariat dan korelasi parsial dengan teknik analisis Pearson Correlations.

\section{HASIL DAN PEMBAHASAN}

\section{Hasil Penelitian}

Nilai yang mencerminkan kondisi aktual setiap variabel didasarkan pada nilai skor rata-rata dan tingkat variansinya.

Tabel 4 Kriteria skor rata-rata

\begin{tabular}{cl}
\hline Rata-Rata Skor & \multicolumn{1}{c}{ Kriteria } \\
\hline $1,00-1,80$ & Sangat Rendah \\
\hline $1,81-2,60$ & Rendah \\
\hline $2,61-3,40$ & Cukup \\
\hline $3,41-4,20$ & Tinggi \\
\hline $4,21-5,00$ & Sangat Tinggi \\
\hline
\end{tabular}

\section{Karakteristik Responden}

Merujuk kepada hasil analisis statistik data penelitian dengan teknik deskriptif, berikut dipaparkan kondisi temuan penelitian:

\section{a. Jenis kelamin}

Tidak

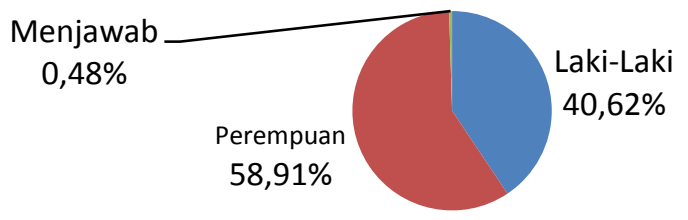

Gambar 1 Karakteristik responden menurut jenis kelamin

\section{b. Etnik}

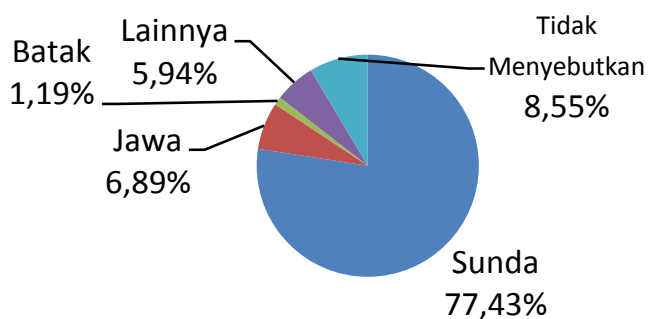

Gambar 2 Karakteristik Responden Menurut Etnik

\section{c. Pekerjaan ayah}

Tidak

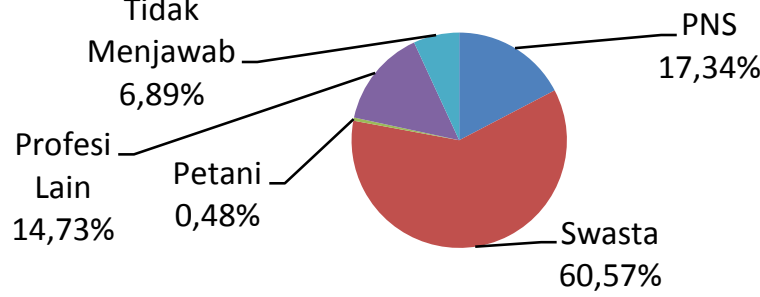

Gambar 3 Karakteristik responden menurut

d. Pekerjaan ibu pekerjaan ayah

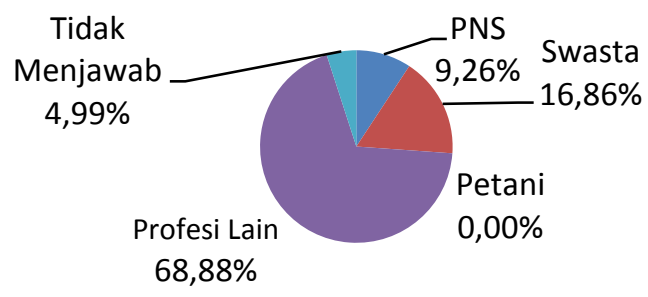

Gambar 4 Karakteristik responden menurut pekerjaan ibu

e. Penghasilan ayah

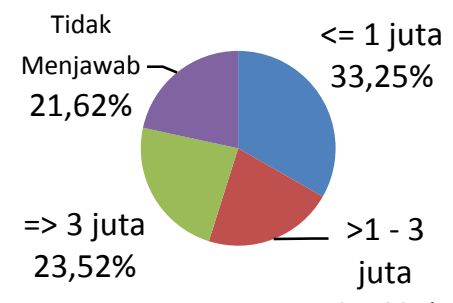

Gambar 5 Karakteristik responden menurut penghasilan ayah

\section{f. Penghasilan ibu}

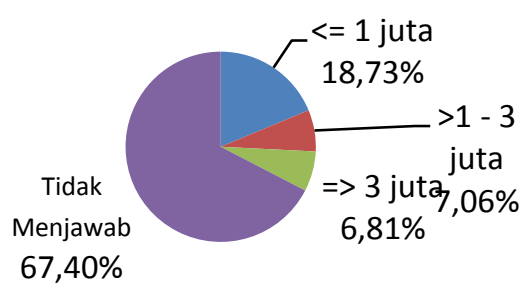

Gambar 6 Karakteristik responden menurut penghasilan ibu 


\section{g. Pendidikan ayah}

Tidak

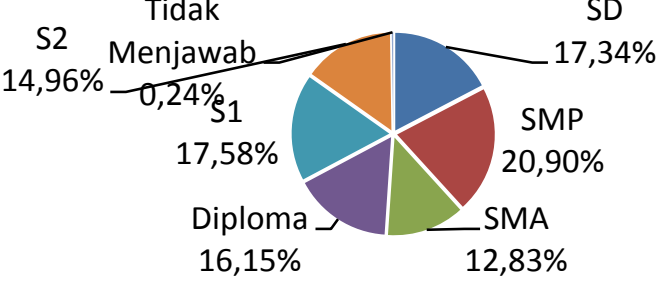

Gambar 7 Karakteristik responden menurut pendidikan ayah

\section{h. Pendidikan ibu}

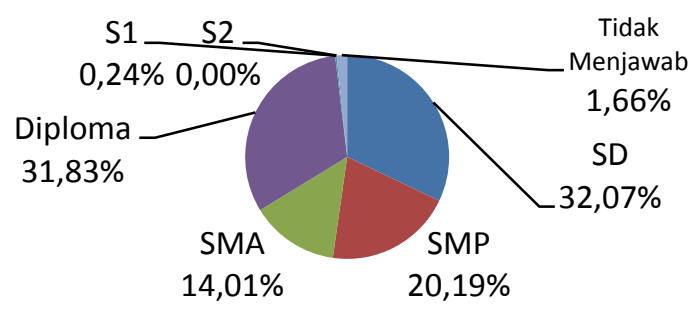

Gambar 8 Karakteristik responden menurut pendidikan ibu

\section{i. Tempat tinggal}

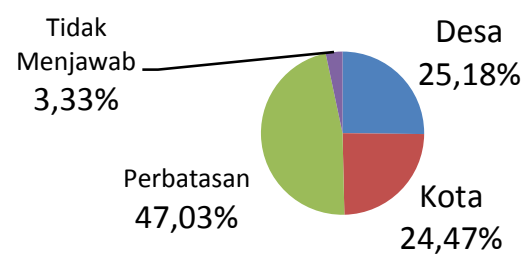

Gambar 9 Karakteristik responden menurut tempat tinggal

\section{Kondisi pembelajaran PKn pada sekolah} menengah di Kota Cimahi

a. Pembelajaran masih berorientasi pada transfer of knowledge sehingga muncul budaya belajar menghapal hal ini disebabkan oleh rendahnya motivasi mengajar pendidik karena menyangkut kemampuan aspek kompetensi pendidik yang dimiliki.

b. Masih dijumpai cara kerja pendidik yang cenderung menganggap bahwa pekerjaannya sebagai pendidik hanya sebagai rutinitas belaka,

c. Penyelenggaraan proses belajar mengajar, sering tidak tepat waktu, sehingga dapat memberikan pengaruh atau contoh yang tidak baik terhadap perkembangan perila$\mathrm{ku}$ pendisiplinan para peserta didik.

d. Mata pelajaran PKn disimpulkan sementara sangat membosankan dan kurang membantu dalam permulaan studi di pendi- dikan tinggi maupun manfaatnya dalam kehidupan bermasyarakat.

\section{Deskripsi Variabel}

\section{a. Variabel Nilai kosmopolitan}

Gambaran umum setiap dimensi variabel nilai kosmopolitan pada sekolah menengah di Kota Cimahi, dilihat dari capaian nilai rata-rata, standar deviasi, persentase, dan kategorinya, disajikan pada tabel 5 berikut:

Tabel 5 Deskripsi setiap dimensi pada variabel nilai kosmopolitan

\begin{tabular}{llrrl}
\hline Dimensi & $\begin{array}{l}\text { Rata- } \\
\text { Rata }\end{array}$ & $\begin{array}{l}\text { Standar } \\
\text { Deviasi }\end{array}$ & $\begin{array}{l}\text { Persen- } \\
\text { tase }\end{array}$ & $\begin{array}{l}\text { Kate- } \\
\text { gori }\end{array}$ \\
\hline Moral & 4,204 & 0,740 & 84,07 & $\begin{array}{l}\text { Sangat } \\
\text { Tinggi }\end{array}$ \\
\hline Politik & 3,936 & 0,815 & 78,72 & Tinggi \\
\hline Budaya & 3,763 & 0,977 & 75,26 & Tinggi \\
\hline $\begin{array}{l}\text { Nilai } \\
\text { kosmopo- } \\
\text { litan }\end{array}$ & 3,952 & 0,882 & 79,05 & Tinggi \\
\hline
\end{tabular}

Sumber: Pengolahan data (2013)

Gambaran umum mengenai nilai kosmopolitan pada sekolah menengah Kota Cimahi sebagaimana tersaji pada tabel 5 tersebut dapat ditampilkan pada gambar 10 berikut.

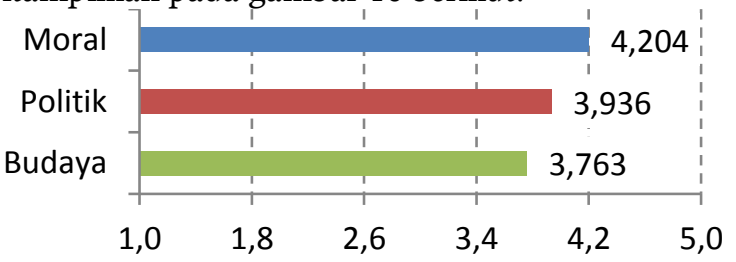

Gambar 10 Capaian rata-rata setiap dimensi pada variabel nilai kosmopolitan

\section{b. Variabel Pembelajaran PKn}

Gambaran umum setiap dimensi pada variabel Pembelajaran PKn, dilihat dari capaian nilai rata-rata, standar deviasi, persentase, dan kategorinya, disajikan pada tabel 6 di bawah ini:

Tabel 6 Deskripsi setiap dimensi pada variabel pembelajaran $\mathrm{PKn}$

\begin{tabular}{lcccl}
\hline Dimensi & $\begin{array}{l}\text { Rata- } \\
\text { Rata }\end{array}$ & $\begin{array}{l}\text { Standar } \\
\text { Deviasi }\end{array}$ & $\begin{array}{l}\text { Persen- } \\
\text { tase }\end{array}$ & Kategori \\
\hline $\begin{array}{l}\text { Civic } \\
\text { Knowledge }\end{array}$ & 3,755 & 0,822 & 75,10 & Tinggi \\
\hline $\begin{array}{l}\text { Civic Skill } \\
\text { Civic }\end{array}$ & 3,345 & 1,168 & 66,90 & Sedang \\
$\begin{array}{l}\text { Disposition } \\
\begin{array}{l}\text { Pembelajara } \\
\text { n PKN }\end{array}\end{array}$ & 3,991 & 0,853 & 79,82 & Tinggi \\
\hline
\end{tabular}

Sumber: Pengolahan data (2013)

Gambaran umum mengenai pembelajaran PKn pada sekolah menengah di Kota Cimahi 
sebagaimana tersaji pada tabel 6 tersebut dapat ditampilkan pada gambar 11 sebagai berikut.

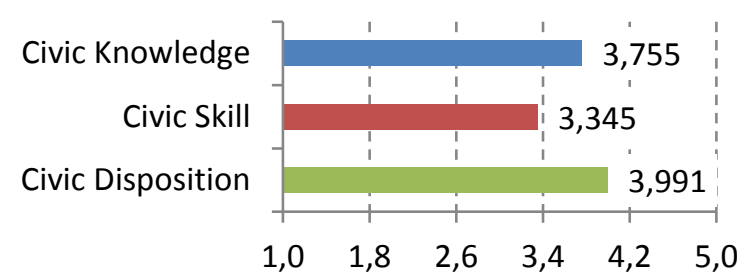

Gambar 11 Capaian rata-rata setiap dimensi pada variabel pembelajaran PKn

\section{c. Perbandingan Variabel Kosmopolitanisme dan Pembelajaran PKn}

Perbandingan jumlah, nilai rata-rata, dan standar deviasi untuk setiap variabel nilai kosmopolitan dan pembelajaran $\mathrm{PKn}$, menurut jenis kelamin, etnis, pekerjaan ayah, pekerjaan ibu, penghasilan ayah, penghasilan ibu, pendidikan ayah, pendidikan ibu, dan tempat tinggal tersaji pada tabel berikut:

Tabel 7 Nilai kosmopolitan dan pembelajaran PKn menurut jenis kelamin

\begin{tabular}{llrr}
\hline $\begin{array}{c}\text { Jenis } \\
\text { Kelamin }\end{array}$ & & $\begin{array}{c}\text { Nilai } \\
\text { Kosmopolitan }\end{array}$ & $\begin{array}{c}\text { Pembelajaran } \\
\text { PKn }\end{array}$ \\
\hline L & N & 171 & 171 \\
& Mean & 97.67 & 110.26 \\
& SD & 9.71 & 15.32 \\
\hline P & N & 248 & 248 \\
& Mean & 99.60 & 107.74 \\
& SD & 8.05 & 12.97 \\
\hline \multirow{2}{*}{ Tdk } & N & 2 & 2 \\
menjawab & Mean & 98.50 & 129.50 \\
& SD & 14.85 & 12.02 \\
\hline Total & N & 421 & 421 \\
& Mean & 98.81 & 108.86 \\
& SD & 8.82 & 14.06 \\
\hline
\end{tabular}

Sumber: Hasil pengolahan data (2013)

Tabel 8. Nilai kosmopolitan dan pembelajaran PKn menurut etnis

\begin{tabular}{llrr}
\hline \multicolumn{1}{c}{ Etnis } & & $\begin{array}{c}\text { Nilai } \\
\text { Kosmo } \\
\text { politan }\end{array}$ & $\begin{array}{c}\text { Pembelajaran } \\
\text { PKn }\end{array}$ \\
\hline Tidak & & & \\
Menjawab & N & 36 & 36 \\
& Mean & 98.00 & 107.39 \\
& SD & 7.23 & 13.00 \\
\hline & N & 326 & 326 \\
& Mean & 98.63 & 109.31 \\
& SD & 8.63 & 14.23 \\
\hline & N & 29 & 29 \\
& Mean & 100.24 & 107.48 \\
& SD & 11.50 & 15.63 \\
\hline 3 & N & 5 & 5 \\
& Mean & 105.80 & 114.20 \\
& SD & 6.42 & 18.93 \\
\hline & N & 25 & 25 \\
& Mean & 99.28 & 105.76 \\
& SD & 9.98 & 10.31
\end{tabular}

\begin{tabular}{llrr}
\hline & & Nilai & \\
Kosmo \\
Etnis & & politan & $\begin{array}{c}\text { Pembelajaran } \\
\text { PKn }\end{array}$ \\
\hline Total & N & 421 & 421 \\
& Mean & 98.81 & 108.86 \\
& SD & 8.82 & 14.06 \\
\hline
\end{tabular}

Sumber: Hasil pengolahan data (2013)

Tabel 9 Nilai kosmopolitan dan pembelajaran $\mathrm{PKn}$ menurut pekerjaan ayah

\begin{tabular}{|c|c|c|c|}
\hline \multicolumn{2}{|c|}{ Pekerjaan Ayah } & $\begin{array}{c}\text { Nilai } \\
\text { Kosmo } \\
\text { politan }\end{array}$ & $\begin{array}{c}\text { Pembelajaran } \\
\text { PKn }\end{array}$ \\
\hline Tidak & $\mathrm{N}$ & 29 & 29 \\
\hline \multirow[t]{2}{*}{ Menjawab } & Mean & 100.03 & 110.90 \\
\hline & $\mathrm{SD}$ & 8.55 & 15.28 \\
\hline \multirow[t]{3}{*}{1} & $\mathrm{~N}$ & 73 & 73 \\
\hline & Mean & 99.52 & 109.95 \\
\hline & $\mathrm{SD}$ & 9.38 & 13.61 \\
\hline \multirow[t]{3}{*}{2} & $\mathrm{~N}$ & 255 & 255 \\
\hline & Mean & 98.41 & 107.86 \\
\hline & $\mathrm{SD}$ & 8.69 & 14.12 \\
\hline \multirow[t]{3}{*}{3} & $\mathrm{~N}$ & 2 & 2 \\
\hline & Mean & 112.50 & 109.00 \\
\hline & $\mathrm{SD}$ & 12.02 & 19.80 \\
\hline \multirow[t]{3}{*}{4} & $\mathrm{~N}$ & 0 & 0 \\
\hline & Mean & N/A & N/A \\
\hline & $\mathrm{SD}$ & $\mathrm{N} / \mathrm{A}$ & $\mathrm{N} / \mathrm{A}$ \\
\hline \multirow[t]{3}{*}{5} & $\mathrm{~N}$ & 62 & 62 \\
\hline & Mean & 98.61 & 110.76 \\
\hline & $\mathrm{SD}$ & 8.56 & 13.74 \\
\hline \multirow[t]{3}{*}{ Total } & $\mathrm{N}$ & 421 & 421 \\
\hline & Mean & 98.81 & 108.86 \\
\hline & SD & 8.82 & 14.06 \\
\hline
\end{tabular}

Sumber: Hasil pengolahan data (2013)

Tabel 10 Nilai kosmopolitan dan pembelajaran

PKn menurut pekerjaan ibu

\begin{tabular}{|c|c|c|c|}
\hline \multicolumn{2}{|c|}{ Pekerjaan Ibu } & $\begin{array}{c}\text { Nilai } \\
\text { Kosmo } \\
\text { politan }\end{array}$ & $\begin{array}{c}\text { Pembelajaran } \\
\text { PKn }\end{array}$ \\
\hline Tidak & $\mathrm{N}$ & 21 & 21 \\
\hline \multirow{2}{*}{ Menjawab } & Mean & 97.29 & 105.95 \\
\hline & $\mathrm{SD}$ & 10.27 & 16.35 \\
\hline \multirow[t]{3}{*}{1} & $\mathrm{~N}$ & 39 & 39 \\
\hline & Mean & 101.62 & 111.90 \\
\hline & $\mathrm{SD}$ & 9.29 & 15.57 \\
\hline \multirow[t]{3}{*}{2} & $\mathrm{~N}$ & 71 & 71 \\
\hline & Mean & 97.62 & 109.51 \\
\hline & $\mathrm{SD}$ & 9.07 & 14.54 \\
\hline \multirow[t]{3}{*}{3} & $\mathrm{~N}$ & 0 & 0 \\
\hline & Mean & N/A & N/A \\
\hline & SD & N/A & $\mathrm{N} / \mathrm{A}$ \\
\hline \multirow[t]{3}{*}{4} & $\mathrm{~N}$ & 0 & 0 \\
\hline & Mean & N/A & $\mathrm{N} / \mathrm{A}$ \\
\hline & $\mathrm{SD}$ & $\mathrm{N} / \mathrm{A}$ & $\mathrm{N} / \mathrm{A}$ \\
\hline \multirow[t]{3}{*}{5} & $\mathrm{~N}$ & 290 & 290 \\
\hline & Mean & 98.83 & 108.51 \\
\hline & $\mathrm{SD}$ & 8.54 & 13.56 \\
\hline \multirow[t]{3}{*}{ Total } & $\mathrm{N}$ & 421 & 421 \\
\hline & Mean & 98.81 & 108.86 \\
\hline & $\mathrm{SD}$ & 8.82 & 14.06 \\
\hline
\end{tabular}

Sumber: Hasil pengolahan data (2013) 
Tabel 11 Nilai Kosmopolitan dan pembelajaran PKn menurut penghasilan ayah

\begin{tabular}{llrr}
\hline & & $\begin{array}{c}\text { Nilai } \\
\text { Kosmo } \\
\text { politan }\end{array}$ & $\begin{array}{c}\text { Pembelajaran } \\
\text { PKn }\end{array}$ \\
\hline Tidak & & & \\
Menjawab & $\mathrm{N}$ & 91 & 91 \\
& Mean & 97.41 & 109.15 \\
& SD & 8.87 & 13.65 \\
\hline & N & 140 & 140 \\
& Mean & 99.20 & 109.34 \\
& SD & 8.86 & 14.53 \\
\hline & N & 91 & 91 \\
& Mean & 99.78 & 109.70 \\
& SD & 8.51 & 11.85 \\
\hline 3 & 99 & 99 \\
& Mean & 98.66 & 107.16 \\
& SD & 8.95 & 15.63 \\
\hline Total & N & 421 & 421 \\
& Mean & 98.81 & 108.86 \\
& SD & 8.82 & 14.06 \\
\hline
\end{tabular}

Sumber: Hasil pengolahan data (2013)

Tabel 12 Nilai kosmopolitan dan pembelajaran PKn menurut penghasilan ibu

\begin{tabular}{|c|c|c|c|}
\hline Penghas & n Ibu & $\begin{array}{c}\text { Nilai } \\
\text { Kosmo } \\
\text { politan }\end{array}$ & $\begin{array}{c}\text { Pembelajaran } \\
\text { PKn }\end{array}$ \\
\hline Tidak & $\mathrm{N}$ & 277 & 277 \\
\hline Menjawab & Mean & 98.07 & 107.52 \\
\hline & SD & 8.66 & 13.55 \\
\hline 1 & $\mathrm{~N}$ & 77 & 77 \\
\hline & Mean & 100.38 & 111.42 \\
\hline & SD & 9.32 & 14.35 \\
\hline 2 & $\mathrm{~N}$ & 29 & 29 \\
\hline & Mean & 98.83 & 114.34 \\
\hline & $\mathrm{SD}$ & 8.76 & 15.01 \\
\hline 3 & $\mathrm{~N}$ & 38 & 38 \\
\hline & Mean & 101.00 & 109.32 \\
\hline & SD & 8.52 & 15.24 \\
\hline Total & $\mathrm{N}$ & 421 & 421 \\
\hline & Mean & 98.81 & 108.86 \\
\hline & SD & 8.82 & 14.06 \\
\hline
\end{tabular}

Sumber: Hasil pengolahan data (2013)

Tabel 13 Nilai kosmopolitan dan pembelajaran PKn menurut pendidikan ayah

\begin{tabular}{|c|c|c|c|}
\hline Pendidika & n Ayah & $\begin{array}{c}\text { Nilai } \\
\text { Kosmo } \\
\text { politan }\end{array}$ & $\begin{array}{c}\text { Pembelajaran } \\
\text { PKn }\end{array}$ \\
\hline Tidak & $\mathrm{N}$ & 1 & 1 \\
\hline Menjawab & $\begin{array}{l}\text { Mean } \\
\text { SD }\end{array}$ & 117 & 95 \\
\hline 1 & $\mathrm{~N}$ & 73 & 73 \\
\hline & Mean & 99.19 & 111.68 \\
\hline & SD & 9.13 & 11.28 \\
\hline 2 & $\mathrm{~N}$ & 88 & 88 \\
\hline & Mean & 97.95 & 109.70 \\
\hline & $\mathrm{SD}$ & 8.87 & 13.06 \\
\hline 3 & $\mathrm{~N}$ & 54 & 54 \\
\hline & Mean & 99.02 & 106.59 \\
\hline & $\mathrm{SD}$ & 10.00 & 13.75 \\
\hline 4 & $\mathrm{~N}$ & 68 & 68 \\
\hline
\end{tabular}

\begin{tabular}{llrr}
\hline & & $\begin{array}{c}\text { Nilai } \\
\text { Kosmo } \\
\text { politan }\end{array}$ & $\begin{array}{c}\text { Pembelajaran } \\
\text { PKn }\end{array}$ \\
\hline \multirow{6}{*}{ Pendidikan Ayah } & Mean & 99.88 & 109.19 \\
& SD & 9.55 & 16.84 \\
\hline & $\mathrm{N}$ & 74 & 74 \\
& Mean & 99.85 & 108.50 \\
& SD & 7.65 & 17.01 \\
\hline & $\mathrm{N}$ & 63 & 63 \\
& Mean & 96.71 & 106.67 \\
& SD & 7.27 & 11.00 \\
\hline Total & $\mathrm{N}$ & 421 & 421 \\
& Mean & 98.81 & 108.86 \\
& SD & 8.82 & 14.06 \\
\hline Sumber: & Hasil pengolahan &
\end{tabular}

Sumber: Hasil pengolahan data (2013)

Tabel 14 Nilai kosmopolitan dan pembelajaran PKn menurut pendidikan ibu

\begin{tabular}{|c|c|c|c|}
\hline \multicolumn{2}{|c|}{ Pendidikan Ibu } & $\begin{array}{c}\text { Nilai } \\
\text { Kosmo } \\
\text { politan }\end{array}$ & $\begin{array}{c}\text { Pembelajaran } \\
\text { PKn }\end{array}$ \\
\hline \multicolumn{4}{|c|}{ Tidak } \\
\hline \multirow[t]{3}{*}{ Menjawab } & $\mathrm{N}$ & 7 & 7 \\
\hline & Mean & 97.29 & 100.00 \\
\hline & $\mathrm{SD}$ & 11.80 & 8.62 \\
\hline \multirow[t]{3}{*}{1} & $\mathrm{~N}$ & 135 & 135 \\
\hline & Mean & 98.90 & 109.68 \\
\hline & $\mathrm{SD}$ & 8.51 & 14.41 \\
\hline \multirow[t]{3}{*}{2} & $\mathrm{~N}$ & 85 & 85 \\
\hline & Mean & 99.24 & 107.27 \\
\hline & $\mathrm{SD}$ & 8.81 & 14.35 \\
\hline \multirow[t]{3}{*}{3} & $\mathrm{~N}$ & 59 & 59 \\
\hline & Mean & 98.02 & 106.08 \\
\hline & $\mathrm{SD}$ & 9.45 & 15.40 \\
\hline \multirow[t]{3}{*}{4} & $\mathrm{~N}$ & 134 & 134 \\
\hline & Mean & 98.79 & 110.59 \\
\hline & $\mathrm{SD}$ & 8.77 & 12.76 \\
\hline \multirow[t]{3}{*}{5} & $\mathrm{~N}$ & 1 & 1 \\
\hline & Mean & 110 & 129 \\
\hline & $\mathrm{SD}$ & & \\
\hline \multirow[t]{3}{*}{ Total } & $\mathrm{N}$ & 421 & 421 \\
\hline & Mean & 98.81 & 108.86 \\
\hline & $\mathrm{SD}$ & 8.82 & 14.06 \\
\hline
\end{tabular}

Sumber: Hasil pengolahan data (2013)

Tabel 15 Nilai kosmopolitan dan pembelajaran PKn menurut tempat tinggal

\begin{tabular}{|c|c|c|c|}
\hline \multicolumn{2}{|c|}{ Tempat Tinggal } & $\begin{array}{c}\text { Nilai } \\
\text { Kosmo } \\
\text { politan }\end{array}$ & $\begin{array}{c}\text { Pembelajaran } \\
\text { PKn }\end{array}$ \\
\hline \multicolumn{4}{|c|}{ Tidak } \\
\hline \multirow[t]{3}{*}{ Menjawab } & $\mathrm{N}$ & 14 & 14 \\
\hline & Mean & 102.86 & 108.86 \\
\hline & $\mathrm{SD}$ & 10.35 & 14.33 \\
\hline \multirow[t]{3}{*}{ Desa } & $\mathrm{N}$ & 106 & 106 \\
\hline & Mean & 99.32 & 108.65 \\
\hline & $\mathrm{SD}$ & 8.13 & 15.45 \\
\hline \multirow[t]{3}{*}{ Kota } & $\mathrm{N}$ & 103 & 103 \\
\hline & Mean & 98.35 & 107.37 \\
\hline & SD & 8.04 & 13.09 \\
\hline \multirow[t]{3}{*}{ Perbatasan } & $\mathrm{N}$ & 198 & 198 \\
\hline & Mean & 98.49 & 109.76 \\
\hline & $\mathrm{SD}$ & 9.41 & 13.80 \\
\hline Total & $\mathrm{N}$ & 421 & 421 \\
\hline
\end{tabular}




\begin{tabular}{rrr}
\hline & Nilai & \\
& Kosmo & Pembelajaran \\
Tempat Tinggal & politan & PKn \\
\hline Mean & 98.81 & 108.86 \\
SD & 8.82 & 14.06 \\
\hline
\end{tabular}

Sumber: Hasil pengolahan data (2013)

\section{Hasil uji persyaratan data}

Hasil pengujian normalitas data menggunakan one-sample Kolmogorov-Smirnov test dapat disajikan sebagai berikut.

Tabel 16 Hasil Pengujian Normalitas Data

\begin{tabular}{|c|c|c|c|c|c|}
\hline \multicolumn{6}{|c|}{ One-Sample Kolmogorov-Smirnov Test } \\
\hline & & Kosmopolitan & Etnisitas & $\mathrm{PKn}$ & Nasionalisme \\
\hline \multirow{3}{*}{ Normal Parameters ${ }^{a, b}$} & & 421 & 421 & 421 & 421 \\
\hline & Mean & 98.81 & 99.50 & 108.86 & 99.46 \\
\hline & Std. Deviation & 8.819 & 9.411 & 14.065 & 8.609 \\
\hline \multirow{3}{*}{ Diff erences } & Absolute & .046 & .049 & .052 & .050 \\
\hline & Positive & .033 & .034 & .052 & .037 \\
\hline & Negative & -.046 & -.049 & -.027 & -.050 \\
\hline Kolmogorov-Smirnov Z & & .945 & 1.006 & 1.063 & 1.032 \\
\hline Asy mp. Sig. (2-tailed) & & .334 & .264 & .208 & .237 \\
\hline
\end{tabular}

Sumber: Hasil pengolahan data (2013)

Pengujian linieritas dilakukan dengan menggunakan uji regresi linear berganda. Hasil dari uji linieritas disajikan sebagai berikut.

Tabel 17 Hasil pengujian linieritas

\begin{tabular}{|c|c|c|c|c|c|c|}
\hline \multicolumn{7}{|c|}{ ANOVA } \\
\hline Model & & $\begin{array}{l}\text { Sum of } \\
\text { Squares }\end{array}$ & df & Mean Square & $\mathrm{F}$ & Sig. \\
\hline 1 & $\begin{array}{l}\text { Regression } \\
\text { Residual } \\
\text { Total }\end{array}$ & $\begin{array}{r}7220.494 \\
23908.185 \\
31128.679\end{array}$ & $\begin{array}{r}3 \\
417 \\
420\end{array}$ & $\begin{array}{r}2406.831 \\
57.334\end{array}$ & 41.979 & $.000^{a}$ \\
\hline
\end{tabular}

Sumber: Hasil pengolahan data (2013) berikut.

Hasil dari uji homogenitas disajikan sebagai

Tabel 18 Hasil pengujian homogenitas

\begin{tabular}{|c|c|c|c|c|c|c|}
\hline \multicolumn{7}{|c|}{ ANOVA } \\
\hline & & Sum of & df & Mean Square & 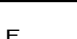 & Sig \\
\hline Kosmopolitan & $\begin{array}{l}\text { Between Groups } \\
\text { Within Groups } \\
\text { Total }\end{array}$ & $\begin{array}{r}6823.832 \\
25840.966 \\
32664.798 \\
\end{array}$ & $\begin{array}{r}45 \\
375 \\
420\end{array}$ & $\begin{array}{r}151.641 \\
68.909\end{array}$ & 2.201 & .000 \\
\hline Etnisitas & $\begin{array}{l}\text { Between Groups } \\
\text { Within Groups } \\
\text { Total }\end{array}$ & $\begin{array}{r}9731.738 \\
27469.511 \\
37201.249 \\
\end{array}$ & $\begin{array}{r}45 \\
375 \\
420\end{array}$ & $\begin{array}{r}216.261 \\
73.252\end{array}$ & 2.952 & .000 \\
\hline PKn & $\begin{array}{l}\text { Between Groups } \\
\text { Within Groups } \\
\text { Total }\end{array}$ & $\begin{array}{l}23298.784 \\
59786.499 \\
83085.283\end{array}$ & $\begin{array}{r}450 \\
375 \\
420\end{array}$ & $\begin{array}{l}517.751 \\
159.431\end{array}$ & 3.247 & .000 \\
\hline
\end{tabular}

Sumber: Hasil pengolahan data (2013)

Hasil pengujian homogenitas menunjukkan bahwa setiap variabel memiliki signifikansi 0,000 yang berarti bahwa setiap variabel memiliki sifat homogen.

\section{Pengujian hipotesis}

Kriteria untuk mengukur tinggi-rendahnya hubungan dan pengaruh variabel eksogen terhadap variabel endogen adalah disajikan sebagai berikut:

Tabel 19 Kriteria pengukuran hubungan dan pengaruh

\begin{tabular}{|c|c|c|c|c|c|c|}
\hline \multicolumn{2}{|c|}{ Korelasi (R) } & \multicolumn{2}{|l|}{ Kategori } & \multicolumn{2}{|c|}{$\begin{array}{l}\text { Pengaruh } \\
\text { (R-Square) }\end{array}$} & \multirow{2}{*}{$\begin{array}{c}\text { Kategori } \\
\text { Sangat Rendah }\end{array}$} \\
\hline 0,000 & 0,199 & Sangat Lemah & $\rightarrow$ & 0,000 & $-0,039$ & \\
\hline 0,200 & 0,399 & Lemah & $\rightarrow$ & 0,040 & 0,159 & Rendah \\
\hline 0,400 & 0,599 & Cukup Kuat & $\rightarrow$ & 0,160 & 0,359 & Cukup Tinggi \\
\hline 0,600 & 0,799 & Kuat & $\rightarrow$ & 0,360 & 0,639 & Tinggi \\
\hline 0,800 & 1,000 & Sangat Kuat & $\rightarrow$ & 0,640 & 1,000 & Sangat Tinggi \\
\hline
\end{tabular}

Sumber: Toharuddin (2012: 136) 
Pengujian hipotesis dilakukan dengan model pengukuran variabel penelitian sebagai berikut:

\section{a. Model pengukuran nilai kosmopolitan}

Berdasarkan model pengukuran, variabel laten eksogen nilai kosmopolitan secara valid dan reliabel dapat dijelaskan oleh tiga dimensi, yaitu moral, politik, dan budaya.

Tabel 20 Hubungan dimensi dengan variabel nilai kosmopolitan

\begin{tabular}{lrrcc}
\hline Dimensi & $\begin{array}{c}\text { Koefisien Validitas } \\
(\mathrm{r})\end{array}$ & Koefisien Reliabilitas $\left(\mathrm{r}^{2}\right)$ & $\begin{array}{c}\text { Varians } \\
\text { Error }\end{array}$ & Keterangan \\
\hline Moral & 0,7881 & 0,6211 & 0,3789 & Signifikan (Valid dan Reliabel) \\
\hline Politik & 0,7794 & 0,6075 & 0,3925 & Signifikan (Valid dan Reliabel) \\
\hline Budaya & 0,6091 & 0,3710 & 0,6290 & Signifikan (Valid dan Reliabel) \\
\hline Koefisien Reliabilitas Konstruk $=$ & 0,7718 & & Reliabel \\
\hline
\end{tabular}

Sumber: Pengolahan Data (2013)

\section{b. Model pengukuran pembelajaran PKn}

Berdasarkan model pengukuran, variabel laten dapat dijelaskan oleh tiga dimensi, yaitu (1) civic knowledge, (2) civic skill, dan (3) civic disposition endogen Pembelajaran PKn secara valid dan reliabel

Tabel 21 Hubungan dimensi dengan variabel pembelajaran PKn

\begin{tabular}{lrrrc}
\hline \multicolumn{1}{c}{ Dimensi } & $\begin{array}{c}\text { Koefisien Validitas } \\
(\mathrm{r})\end{array}$ & Koefisien Reliabilitas $\left(\mathrm{r}^{2}\right)$ & $\begin{array}{c}\text { Varians } \\
\text { Error }\end{array}$ & Keterangan \\
\hline Civic Knowledge & 0,4078 & 0,1663 & 0,8337 & Tidak Signifikan \\
\hline Civic Skill & 0,5928 & 0,3514 & 0,6486 & Signifikan (Valid dan Reliabel) \\
\hline Civic Disposition & 0,7573 & 0,5735 & 0,4265 & Signifikan (Valid dan Reliabel) \\
\hline \multicolumn{2}{c}{ Koefisien Reliabilitas Konstruk $=$} & 0,6182 & & Cukup Reliabel \\
\hline
\end{tabular}

Sumber: Pengolahan Data (2013

\section{Pembahasan}

\section{Pengaruh nilai kosmopolitan terhadap pembelajaran PKn}

Pengujian hipotesis 1 menunjukkan bahwa nilai kosmopolitan secara simultan memiliki pengaruh yang tinggi terhadap pembelajaran PKn (dengan R sebesar 0,4296 dan 0,5229 dan R-Square sebesar 0,6971). Perhitungan ini menunjukkan bahwa pengaruh nilai kosmopolitan terhadap pembelajaran PKn besar pada sekolah menengah di Kota Cimahi.

\section{Pengaruh nilai kosmopolitan terhadap pembelajaran PKn}

Secara keseluruhan, pengujian hipotesis 2 menunjukkan bahwa nilai kosmopolitan, dan pembelajaran PKn secara simultan memiliki pengaruh yang tinggi (dengan koefisien $\mathrm{R}$ masingmasing sebesar 0,2081; 0,2242; dan 0,3749 dengan R-Square sebesar 0,5206). Perhitungan ini menunjukkan bahwa secara langsung pengaruh pembelajaran PKn besar terhadap nilai kosmopolitan peserta didik pada sekolah menengah Kota Cimahi.

\section{KESIMPULAN}

Kesimpulan dari penelitian ini adalah bahwa dampak nilai kosmopolitan pada siswa sekolah menengah di Kota Cimahi terhadap pembelajaran $\mathrm{PKn}$ sudah signifikan (dengan $\mathrm{R}^{2}=0,6971$ atau $69,71 \%$ ). Hal ini menunjukkan adanya proses harmonisasi nilai kosmopolitan pada siswa sekolah menengah dalam pembelajaran PKn. Nilai kosmo- politan dan pembelajaran PKn juga berdampak secara signifikan (dengan $\mathrm{R}^{2}=0,5200$ atau $52,00 \%$ ). Hal tersebut menunjukkan bahwa harmonisasi nilai kosmopolitan yang dibelajarkan dalam proses pembelajaran PKn yang bermutu berpengaruh pada peserta didik sekolah menegah di Kota Cimahi. Dalam hal ini, pembelajaran PKn memiliki pengaruh paling tinggi $(24,18 \%)$. Harmonisasi nilai kosmopolitan yang dibelajarkan dalam proses pembelajaran PKn berdasarkan kurikulum 2013 sangat berpengaruh. Dengan kata lain nilai kosmopolitan menjadi faktor yang sangat menentukan dalam mengembangkan pembelajaran PKn. berikut:

Secara khusus, dapat disimpulkan sebagai

1. Sikap nilai kosmopolitansiswa berada pada kategori tinggi, yang ditandai oleh adanya pemahaman atau gagasan bahwa semua manusia, tanpa memandang latar belakangnya adalah anggota dari sebuah komunitas tertentu.

2. Pembelajaran PKn belum secara merata mengembangkan dimensi pengetahuan kewarganegaraan (civic knowledge), kebajikan kewarganegaraan (civic disposition), dan kecakapan kewarganegaraan (civic skill). Pada dasarnya konsep dan paradigma PKn di abad 21 menghendaki konseptualisasi warga negara multidimensional yang mencakup empat dimensi yakni personal, sosial, temporal dan spatial dalam rangka melibatkan peserta didik 
di masyarakat untuk mendapatkan pengalaman.

3. Terjadinya harmonisasi nilai kosmopolitan berpengaruh positif dan signifikan terhadap pembelajaran PKn. Dalam mengembangkan kurikulum dan pembelajaran di kelas, pendidik hendaknya memahami bahwa kebajikan warga negara dan keterampilan intelektual dan partisipasi tidak terpisahkan dari pengetahuan warga negara (a body of knowledge) sehingga melalui PKn, peserta didik dapat menggali civic knowledge, civic disposition dan civic skills yang diaplikasikan dalam kehidupan sehari-hari

\section{DAFTAR PUSTAKA}

Delanty, G. (2006). The cosmopolitan imagination: Critical cosmopolitanism and social theory. British Journal of Sociology, 57(1), 25-47. https://doi.org/10.1111/j.14684446.2006.00092.x

Giddens, A. (2004). Konsekuensi-konsekuensi modernitas. Yogyakarta: Kreasi Wacana.

Held, D., McGrew, A., Goldblatt, D., \& Perraton, J. (1999). Introduction. In Global Transformations: Politics, Economics and Culture (hal. 1-31).

Kalidjernih, F. K. (2009). Puspa ragam konsep dan isu kewarganegaraan. Bandung: Widya Aksara Press.

Kalidjernih, F. K. (2011). Puspa ragam konsep dan isu kewarganegaraan (3 ed.). Bandung: Widya Aksara Press.

Mau, S., Mewes, J., \& Zimmermann, A. (2008). Cosmopolitan attitudes through transnational social practices? Global Networks, 8(1), 1-24. https://doi.org/10.1111/j.14710374.2008.00183. $\mathrm{x}$

Micklethwait, J., \& Wooldridge, A. (2008). A future perfect: The challenge and promise of globalization. New York: Random House Publishing Group. Diambil dari https://books.google.co.id/books?id=iQUA oi2IQiwC

Oommen, T. K. (2009). Kewarganegaraan, kebangsaan, \& etnisitas: mendamaikan persaingan identitas. Yogyakarta: Kreasi Wacana. Diambil dari https://books.google.co.id/books?id=w06g MwEACAAJ

Tilaar, H. (2002). Perubahan sosial dan pendidikan. Jakarta: Grasindo.

Winataputra, U. S. (2004). Pendidikan kewarganegaraan dalam perspektif pencerdasan kehidupan bangsa. Jakarta: Universitas Terbuka. 